
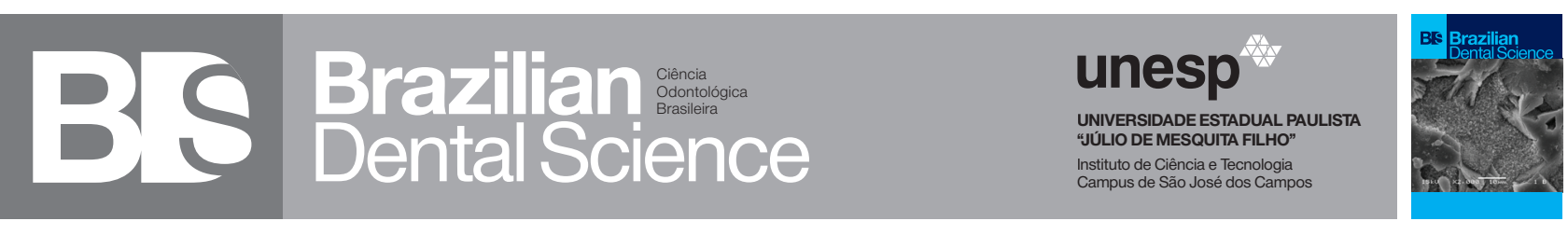

\title{
Endodontic treatment of a large periapical cyst with the aid of antimicrobial photodynamic therapy: case report
}

Tratamento endodôntico de um grande cisto periapical com o auxílio de terapia fotodinâmica antimicrobiana: relato de caso

Amjad ABU HASNA ${ }^{1}$, Carlos Henrique FERRARI ${ }^{1}$, Cláudio Antonio Talge CARVALHO ${ }^{1}$

1 - São Paulo State University (Unesp) - Institute of Science and Technology, São José dos Campos - Department of Restorative Dentistry Endodontic Division - São José dos Campos - SP - Brazil.

\begin{abstract}
Introduction: Periapical cysts, especially those of great extension, represent a challenge for endodontics, due to the ineffectiveness of traditional root canal treatment (RCT) in such cases. The aim of this case report was to evaluate the effectivity of antimicrobial photodynamic therapy "aPDT" when associated with calcium hydroxide $\mathrm{Ca}(\mathrm{OH})_{2}$ in treating such cysts. Case report: A 40-years-old female patient complained of bulging in the upper anterior region of the mouth. The clinical examination showed an extensive swollen periodontal area, painful with digital palpation, with a negative response to thermal tests on teeth 11 and 21. After traditional RCT, the canals of teeth 11 and 21 were filled with photosensitizer methylene blue $0.005 \%$ for 5 min pre irradiation time (PIT) and irradiated by low power diode laser with visible red wavelength $(660 \mathrm{~nm})$ during 2 minutes without intervals, using an optical fiber delivering system with a helical movement from apical to cervical. Then the canals were filled with $\mathrm{Ca}(\mathrm{OH})_{2}$ paste for 45 days and had been changed each 15 days, and repeating the radiation. Results: After 45 days, the patient already had a bulging remission, with painless resistance to the apical pressure over the region and signs of bone repair confirmed with the radiographic examination, and total absence of signs or symptoms. Conclusion: the association of aPDT with $\mathrm{Ca}(\mathrm{OH})_{2}$ paste is effective in treating of periapical lesions of great extension and avoids surgical treatment.
\end{abstract}

\section{KEYWORDS}

Antimicrobial; Calcium hydroxide; Diode Laser; Periapical cysts; Photodynamic Therapy; Root canal treatment.

\section{RESUMO}

Introdução: os cistos periapicais, especialmente os de grande extensão, representam um desafio para a endodontista, uma vez que não são reparados com o tratamento endodôntico tradicional. $\mathrm{O}$ objetivo deste relato de caso foi avaliar a efetividade da terapia fotodinâmica antimicrobiana "aPDT" quando associada ao hidróxido de cálcio $\mathrm{Ca}(\mathrm{OH}) 2$ no tratamento desses cistos. Relato de caso: paciente do sexo feminino, 40 anos, com queixa de abaulamento na região ântero-superior da boca. O exame clínico evidenciou extensa área periodontal inchada, dolorosa com palpação digital, com resposta negativa aos testes térmicos dos dentes 11 e 21 . Após o tratamento endodôntico tradicional, os canais dos dentes 11 e 21 foram preenchidos com fotossensibilizador de azul de metileno a $0,005 \%$ de tempo de pré-radiação de 5 min e irradiados por laser de diodo de baixa potência com comprimento de onda vermelho visível (660 $\mathrm{nm}$ ) por $2 \mathrm{~min}$ sem intervalos, usando um sistema de fornecimento de fibra ótica com um movimento helicoidal do apical ao cervical. Em seguida, o canal foi preenchido com pasta de $\mathrm{Ca}(\mathrm{OH}) 2$ por 45 dias sendo trocados a cada 15 dias e repetida a radiação. Resultados: Após 45 dias, o paciente já apresentava uma remissão volumosa, com resistência indolor à pressão apical na região e sinais de reparo ósseo ao exame radiográfico e ausência total de sinais ou sintomas. Conclusão: a associação de aPDT com $\mathrm{Ca}(\mathrm{OH}) 2$ é eficaz no tratamento de lesões periapicais de grande extensão e evitar tratamento cirúrgico.

\section{PALAVRAS-CHAVE}

Antimicrobial; Hidróxido de cálcio; Laser de Diodo; Cistos periapicais; Terapia fotodinâmica; Tratamento do canal radicular. 


\section{INTRODUCTION}

$\mathrm{T}$

he treatment of periapical diseases and alterations of the teeth has been considered as a challenge for professionals due to the difficulty in root canal disinfection [1]. A lot of microorganisms said to be resistant against calcium hydroxide " $\mathrm{Ca}(\mathrm{OH})_{2}$ " like F. nucleatum ssp. Vincentii, Enterococcus faecium [2], and Enterococcus faecalis "E. faecalis" which leads to the root canal treatment "RCT" failure $[3,4]$, as well as yeast like Candida albicana "C.albicana" which results in failure too [5]. Even more $\mathrm{Ca}(\mathrm{OH})_{2}$ considered as ineffective intracanal medication over Streptococcus sanguis [6,7]. However, in another study, $\mathrm{Ca}(\mathrm{OH})_{2}$ paste showed to be effective in root canal disinfection, and specifically over E.faecalis and C.albicana [8].

This doubt and uncertainty in the effectivity of $\mathrm{Ca}(\mathrm{OH})_{2}$ as intracanal medication, promoted a lot of studies to investigate a complementary techniques that could be used in addition to $\mathrm{Ca}(\mathrm{OH})_{2}$, like antimicrobial photodynamic therapy "aPDT", which showed to be effective in association with an interappointment dressing with $\mathrm{Ca}(\mathrm{OH})_{2}$, even more it stimulated repair [9]. The aPDT demonstrated antimicrobial effects in various studies using different wavelengths of the low power laser or LEDs, since specific and high absorption by a non-toxic photoactive dye, called a photosensitizer in the presence of oxygen promoting the photochemical reaction and production of reactive oxygen specimens (ROS) like hydroxyl, superoxide anion, Triplet Oxygen and Singlet Oxygen [10], which contributes to microorganisms disinfection. This procedure is a complementary technique beside irrigating solutions or intracanal medications [11,12], as well as being compatible and without thermal side effects over the surrounding tissue $[12,13]$.

\section{CASE REPORT}

A 40-years-old female patient presented with a history of recent orthodontic treatment, without radiographic follow-up complaining of a bulging in the upper anterior region of the mouth. The clinical examination showed darkening in tooth 11 and an extensive swollen periodontal area, painful with digital palpation, with a negative response to thermal tests on teeth 11 and 21.

Teeth 11 and 21 presented with pulpal necrosis due to the negative response of cold thermal test realized by refrigerant gas (Endo Ice, Maquira Dental products industry LTDABrazil) and relative isolation by cotton rolls and dental saliva ejector, the apical region while tested by digital palpation and perpendicular percussion was painful due to the presence of periapical lesion, with no fistula but with orthodontic trauma history. The depth of its gingival pocket varied between $1-3 \mathrm{~mm}$ with various exploring locations and grade I mobility.

The neighboring teeth 13, 12, 22 and 23 presented vital pulp confirmed by positive response of cold thermal test (Endo Ice), with the same way realized with teeth 11 and 12. There was no periapical pain related to the corresponding teeth, with no fistula or trauma history. The depth of the gingival pockets varied between 1-2 mm with various exploring locations and grade II mobility of Miller classification.

The radiographic and tomographic examination showed extensive bone loss in the anterior region, with rupture of the buccal and palatine cortical bones. The lesion was extensive and rounded with defined borders. All the examined teeth presented complete root formation, with no teeth fracture or calcifications (Figure 1). The biopsy revealed a fluid with radicular cyst characteristics which confirmed latterly by histopathological examination. 
The procedure included RCT of teeth 11 and 21. After absolute isolation, and access cavity, a foraminal debridement took place 1 mm beyond the apex by K-file \#10 (Dentsply Ind. Com. Ltda, Petrópolis, RJ, Brazil). Then the working length was determined by apex locator (Raypex 6, VDW, Munich, Germany) using K-file \#15, and in sequence the instrumentation took place with step-back technique using K-file \#20, 25, 30, and 35 standardizing on working length, and K-file \#40, 45, retracting 1, $2 \mathrm{~mm}$ of the working length respectively. With irrigating of $5 \mathrm{~mL}$ of sodium hypochlorite "NaOCl" 2.5\% with each instrument change, totalizing $30 \mathrm{~mL}$ of irrigation. Next, the canals were filled with Ethylenediaminetetraacetic acid "EDTA" for 3 min activating with K-file \#25. Then the canals were washed each one with $10 \mathrm{~mL}$ of sterile saline solution to remove the EDTA and dried with paper points \#35. Later on, the canals of teeth 11 and 21 were filled with methylene blue $0.005 \%$ (VETEC Quimica Fina LTDA, Rio de Janeiro, RJ, Brazil) and waited for pre irradiation time (PIT) of $5 \mathrm{~min}$. The irradiation procedure was performed using an optical fiber delivering system $(0.40 \mathrm{~mm}$ diameter and $16 \pm 0.5 \mathrm{~mm}$ active surface length) was placed into the canal and the low power diode Laser (MMOptics Ltda, São Carlos, Brazil) with visible red wavelength of $660 \mathrm{~nm}$ and output power of $100 \mathrm{~mW} / \mathrm{cm}^{2}$ was activated for $2 \mathrm{~min}$ without interval, using a helical movement from apical to cervical direction. An energy density of approximately $120.0 \mathrm{~J} / \mathrm{cm}^{2}$ was applied into each canal (Figure 2) [14]. Then the methylene blue was washed out by $10 \mathrm{~mL}$ of sterile saline solutions irrigation and dried out with paper points \#35. Then $\mathrm{Ca}(\mathrm{OH})_{2}$ paste (Ultracal, Ultradent Products, Indaiatuba, SP, Brazil) was inserted in the canals for 15 days, where it was removed by sterile saline solution and re-instrumented by K-file \#35. A new aPDT application was realized and a new $\mathrm{Ca}(\mathrm{OH})_{2}$ paste was inserted again for 15 days.
The same procedure was repeated thirdly, totalizing 45 days of intracanal medication and three sessions of aPDT application.

After 45 days, the patient already had a bulging remission, with painless resistance to apical pressure in the region and signs of bone repair at the radiographic examination, in addition to the total absence of signs or symptoms (Figure 3). Then, the canals were obturated by disinfected Gutta percha cones with $\mathrm{NaOCl} 2.5 \%$ for 1 minute and restored with temporary filing of glass ionomer cement (Ivoclar Vivadent Ltda, Barueri - SP Brazil). After six months the patient was recalled for control radiographic exams (Figure 4).

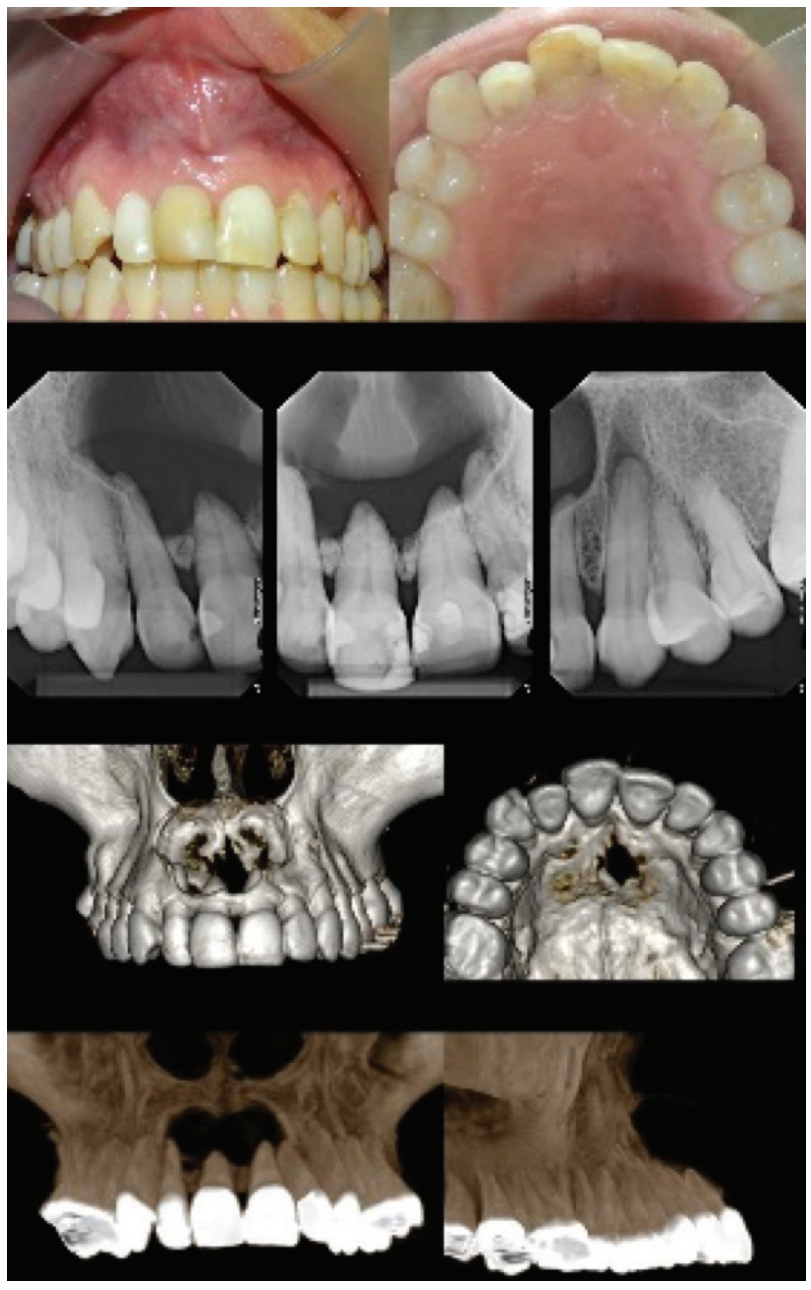

Figure 1 - Initial intraoral examinations, frontal and occlusal photos; periapical radiographs; computed tomography. 3D Reconstructions. 


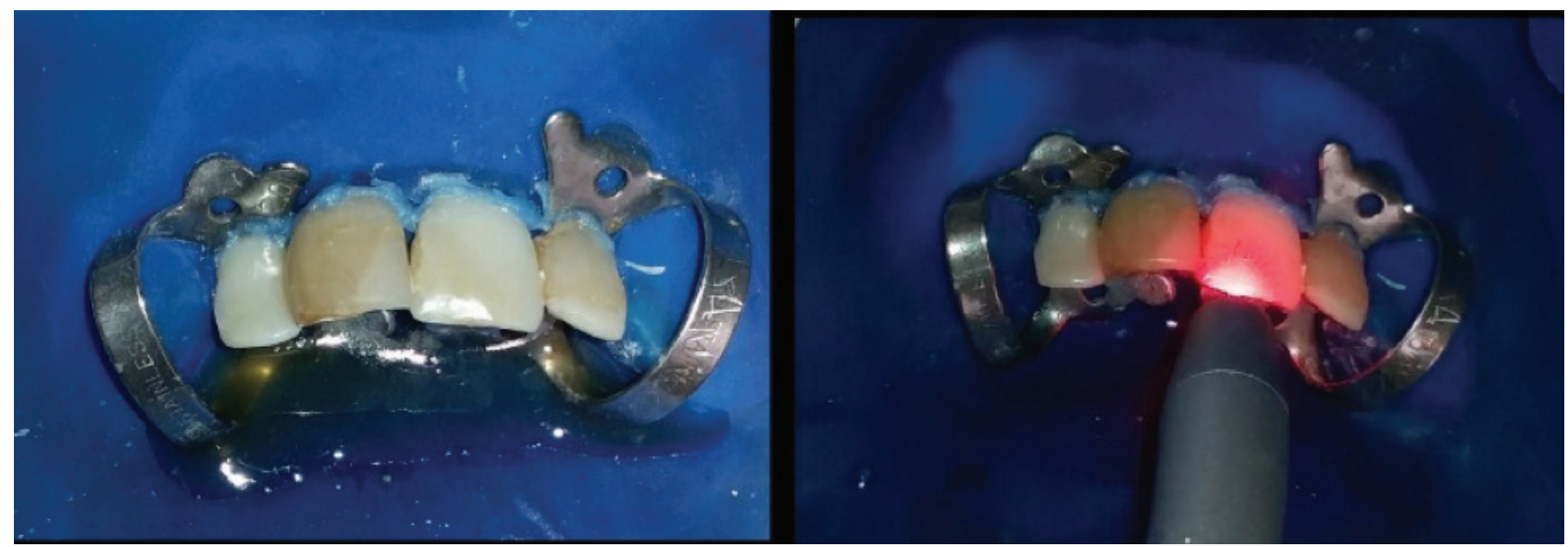

Figure 2 - Intracanal drainage of cystic content. Application of photodynamic therapy after disinfection of root canals.

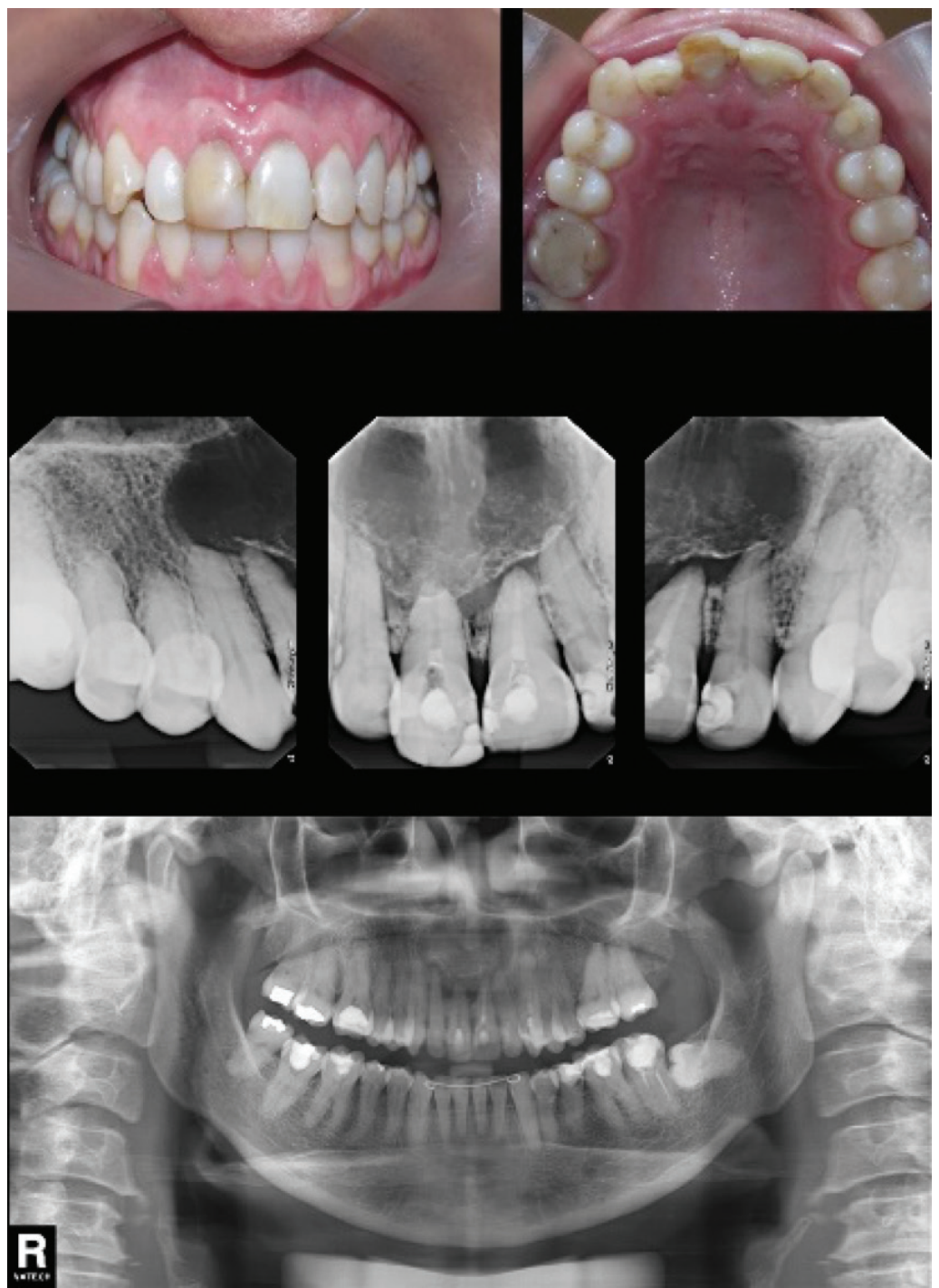

Figure 3 - Control after 45 days of intracanal medication exchanges. Intraoral frontal and occlusal photos and periapical radiographs. 


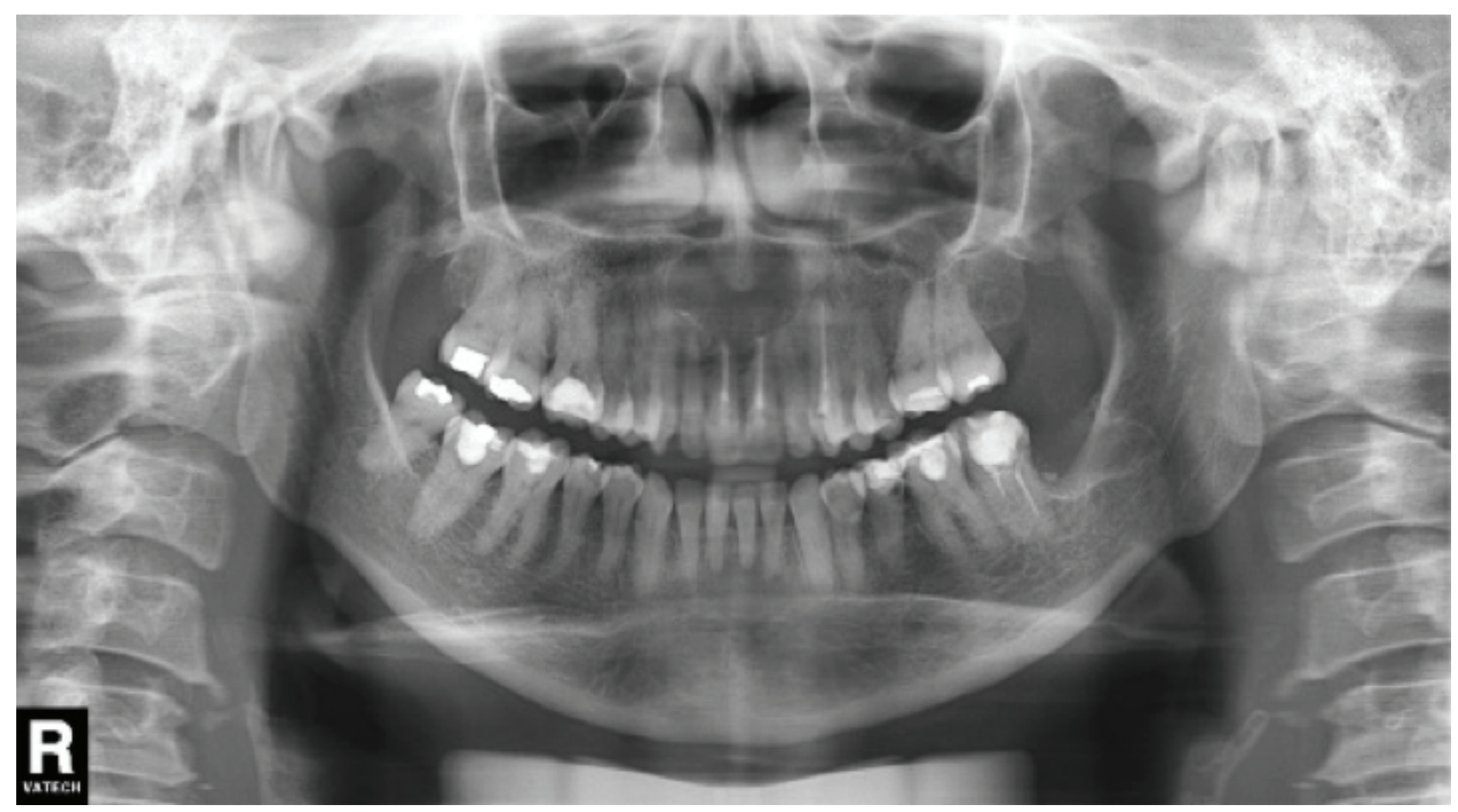

Figure 4 - Control after 180 days. Panoramic radiography. Finished endodontic treatment and absence of signs and symptoms.

\section{DISCUSSION}

This case report aimed to mention the success achieved by the association of aPDT as a complementary technique that collaborate in microorganism reduction in the root canal system with the $\mathrm{Ca}(\mathrm{OH})_{2}$ paste the wide used intracanal medication. This association was able to disinfect the canal, to improve the repair of the periapical lesion, and to heal the disease in terms of absence of signs and symptoms.

Despite the significant progress achieved with rotary systems of instrumentation, the biomechanical preparation (BMP) effectiveness is still limited due to the complex and variable anatomy of the root canal, which results in untouched regions that favor the retention of bacteria and debris [15]. Even more, Siqueira, et al. [16], in their study evaluating the antimicrobial action of $\mathrm{NaOCl}$ at different concentrations revealed that $\mathrm{NaOCl}$ is capable of eliminating microorganisms existed in the canal lumen. However, they remain inside the dentinal tubules, necessitating ,thus, the use of intracanal medication as a complementary procedure, or aPDT application which collaborates in root canal disinfection [11].

Estrela, Estrela, Pécora et al. (2003) [17], in their study evaluating the needed time for $\mathrm{Ca}(\mathrm{OH})_{2}$ to eliminate S. aureus, E.faecalis, P. aeruginosa, B. subtilis, C. albicans, concluded that $\mathrm{Ca}(\mathrm{OH}) 2$ paste was able to eliminate these microorganisms only after 60 days, and the same period for canal infected by a mix of the same microorganisms. The paste of $\mathrm{Ca}(\mathrm{OH})_{2}$ said to be ineffective as intracanal medication over specific types of microorganisms [6,7], which may necessitate the use of reliable techniques that collaborate in the success of RCT [12].

In this case report, aPDT collaborated in the success of RCT due to its antimicrobial action, which has been proved in other studies $[9,18]$. The aPDT revealed the success of the RCT in this case, in terms of absence of signs and symptoms, which agree with another case report [18], in which no intracanal medication was used in association of aPDT. In the same case report revealed no signs or symptoms 
related by the patient which presented clinical success.

In a recent study [19] revealed that both aPDT and $\mathrm{Ca}(\mathrm{OH})_{2}$ are effective in root canal disinfection. In this case report the proposal was to associate both of aPDT and $\mathrm{Ca}(\mathrm{OH})_{2}$ to obtain grater microorganisms reduction, as well as to harness the repair feature of aPDT. However, aPDT itself do not promote tissue healing or repair, but it may optimize repair by modulating inflammatory process.

In addition to the rapid repair of the extensive lesion, which normally needs a surgical intervention to remove the cyst, these results agree with the results of another case report, where no surgical intervention was realized, but a aPDT application [20]. aPDT capacity in repair and healing is confirmed by a lot of case reports over various types of oral lesions [21-23], which agree with the results of this case report. In addition, aPDT has the capacity to eliminate Staphylococcus aureus and Escherichia coli, when used with malachite green photosensitizer.

With the rapid development of aPDT, new photosensitizers, lasers or LEDs equipments and fiber optical delivering systems with a wide variety of features are available and are used in several areas of Dentistry, including Endodontics to promote effective antimicrobial results [24]. Since the high power lasers promoted photothermal effects on the tissues, and depending on the appropriated wavelength and parameters selected damages could be observed, such cement liquefaction, root resorption and periapical necrosis [25]. However, low-power lasers or LED can be used in aPDT as it produces a monochromatic beam with a specific wavelength and absorption to specific photosensitizers in presence of oxygen promotes photochemical reactions, with local ROS production. Low power diode laser with wavelengths ranging from 625 to $805 \mathrm{~nm}$ (red and infrared lights) were effective in using aPDT to eliminate E.faecalis in root canals, according to these results concluded in a systematic literature review, in which toluidine blue and/or methylene blue were used as photosensitizers [24].

Low power diode laser or LEDs were indicated in the literature to be used in the laser therapy procedures in oral tissues. The laser therapy improve the healing and repair of oral lesions in which it can be used in a direct contact or at a very close distance to the application site, avoiding possible harms to the surrounding tissues, which makes it much safer than other sources of laser [26,27]. Laser therapy has no need to use photosensitizer, the light source from the laser or the LED has a direct action over the lesion area and this light is highly absorbed by the soft tissues and poorly absorbed by the hard tissues like teeth and bones [28].

In this case report, the methylene blue $0.005 \%$ was used as a photosensitizer, however, other concentrations could be used [29]. Even more, different photosensitizers could be used like toluidine blue [19] and phenothiazin-5-ium,3,7-bis(dimethylamino),chloride [11]. Knorst, et al. (2019) [30] evaluated various formulas of methylene blue at different $\mathrm{pH}$ and concluded that methylene blue formulations with oxygen carrier and $\mathrm{pH}$ 7.4 resulted in higher antimicrobial effect over biofilms of Pseudomonas aeruginosa.

In this case report, the laser was irradiated using an optical fiber that deliver the light more effectively to the canal. Garcez, et al. [31] concluded that the use of optical fiber or diffusor favors the laser effectivity than in direct contact or without optical fiber method.

Due to the extension and size of the lesion, three sessions of aPDT and $\mathrm{Ca}(\mathrm{OH})_{2}$ paste changes took place in this case report, to confirm a low level of micro-organisms before the obturation, as well as to improve the healing of the lesion by aPDT. In another case report [18], 2 sessions of aPDT was realized using similar wavelength, output power, radiation time, and photosensitizer concentration, but one session of intracanal medication in which 
$\mathrm{Ca}(\mathrm{OH})_{2}$ was used but with another commercial format. However, similar results were obtained after six months.

The aPDT, is a favorable and effective procedure in terms of root canal disinfection, and healing of lesions, which contribute to the success of RCT. However, more clinical studies should take place to evaluate this success over long periods. Some studies in the literature still in doubts about the effectivity of aPDT $[24,32,33]$, even more, aPDT is not effective alone and should be used in association of irrigants. [33]

\section{CONCLUSION}

The aPDT is effective when used with $\mathrm{Ca}(\mathrm{OH}) 2$ paste as intracanal medication and collaborate to the success of RCT.

\section{CONFLICT OF INTEREST}

No potential conflict of interest relevant to this article was reported.

\section{ACKNOWLEDGEIMENTS}

We declare that all authors have contributed significantly to this manuscript and are in agreement with the manuscript. The authors deny any conflict of interest.

\section{REFERENCES}

1. Babaji P, Jagtap K, Lau H, Bansal N, Thajuraj S, Sondhi P.Comparative evaluation of antimicrobial effect of herbal root canal irrigants (Morinda citrifolia, Azadirachta indica, Aloe vera) with sodium hypochlorite: an in vitro study. J Int Soc Prev Community Dent. 2016 May-Jun;6(3):196-9. doi: 10.4103/2231-0762.183104

2. Ferreira NS, Martinho FC, Cardoso FGR, Nascimento GG, Carvalho CAT, Valera MC. Microbiological profile resistant to different intracanal medications in primary endodontic infections. J Endod. 2015 Jun;41(6):824-30. doi: 10.1016/j. joen.2015.01.031

3. Tonea A, Badea M, Oana L, Sava S, Vodnar D. Antibacterial and antifungal activity of endodontic intracanal medications. Clujul Med. 2017;90(3):344-7. doi: 10.15386/cjmed-750.

4. Sedgley C, Buck G, Appelbe 0. Prevalence of Enterococcus faecalis at multiple oral sites in endodontic patients using culture and PCR.J Endod. 2006 Feb;32(2):104-9. doi: 10.1016/j.joen.2005.10.022

5. Mohammadi Z, Shalavi S, Yazdizadeh M. Antimicrobial activity of calcium hydroxide in endodontics: a review. Chonnam Med J.2012 Dec:48(3):133-40. doi: 10.4068/cmi.2012.48.3.133.

6. DiFiore PM, Peters DD, Setterstrom JA, Lorton L. The antibacterial effects of calcium hydroxide apexification pastes on Streptococcus sanguis. Oral Surg Oral Med Oral Pathol. 1983 Jan;55(1):91-4. doi: 10.1016/0030-4220(83)90313-4

7. Siqueira JF,Lopes HP, de Uzeda M. Recontamination of coronally unsealed root canals medicated with camphorated paramonochlorophenol or calcium hydroxide pastes after saliva challenge. J Endod. 1998 Jan;24(1):11-4. doi 10.1016/S0099-2399(98)80204-5

8. Valera MC, Silva KCG da, Maekawa LE, Carvalho CAT, Koga-Ito CY,Camargo $\mathrm{CHR}$, etal. Antimicrobial activity of sodium hypochlorite associated with intracanal medication for Candida albicans and Enterococcus faecalis inoculated in root canals. J Appl Oral Sci. 2009 Dec;17(6):555-9. doi: 10.1590/ s1678-77572009000600003

9. Trindade AC, de Figueiredo JAP, de Oliveira SD, Barth Junior VC, Gallo SW, Follmann C, et al. Histopathological, microbiological, and radiographic analysis of antimicrobial photodynamic therapy for the treatment of teeth with apical periodontitis: a study in rats' molars. Photomed Laser Surg. 2017 Jul;35(7):364371. doi:10.1089/pho.2016.4102

10. Lee MT,Bird PS, Walsh LJ. Photo-activated disinfection of the root canal: a new role for lasers in endodontics. Australian Endodontic Journal. 2004 Dec;30(3):93-98 AustEndod J.2004 Dec;30(3):93-8.

11. Hoedke D, Enseleit C, Gruner D, Dommisch H, Schlafer S, Dige I, et al. Effect of photodynamic therapy in combination with various irrigation protocols on an endodontic multispecies biofilm ex vivo. Int Endod J. 2018 Jan;51Suppl 1:e23-e34. doi: 10.1111/iej.12763. Epub2017 Apr 10.

12. Masuda Y,Sakagami H, Horiike M, Kadokura H, Yamasaki T,Klokkevold PR, et al. Photodynamic Therapy with Pyoktanin Blue and Diode Laser for Elimination of Enterococcus faecalis. In Vivo. 2018 Jul-Aug;32(4):707-712. doi:10.21873/ invivo.11298.

13. Schulte-Lünzum R, GutknechtN, Conrads G, Franzen R. The impact of a $940 \mathrm{~nm}$ diode laser with radial firing tip and bare end fiber tip on enterococcus faecalis in the root canal wall dentin of bovine teeth: an in vitro study. Photomed Laser Surg. 2017 Jul;35(7):357-363. doi: 10.1089/pho.2016.4249.

14. Schneider M, Kirfel G, Berthold M, Frentzen M, Krause F,Braun A. The impact of antimicrobial photodynamic therapy in an artificial biofilm model. Lasers Med Sci. 2012 May;27(3):615-20. doi: 10.1007/s10103-011-0998-7.

15. Gomes BPFA, Pinheiro ET, Gadê-Neto CR, Sousa ELR, Ferraz CCR, Zaia AA, et al. Microbiological examination of infected dental root canals. Oral Microbiol Immunol.2004 Apr;19(2):71-76.

16. Siqueira JF, Rôças IN, Favieri A, Lima KC. Chemomechanical reduction of the bacterial population in the root canal after instrumentation and irrigation with 1\%, 2.5\%, and 5.25\% sodium hypochlorite. J Endod. 2000 Jun;26(6):331-4. doi: 10.1097/00004770-200006000-00006

17. Estrela C, Estrela CR de A, Pécora JD. A study of the time necessary for calcium hydroxide to eliminate microorganisms in infected canals. J Appl Oral Sci.2003 Jun;11(2):133-7. doi:10.1590/s1678-77572003000200009.

18. Firmino RT, Brandt LMT, Ribeiro GL, Dos Santos KSA, Catão MHC de V, Gomes DQ de C. Endodontic treatment associated with photodynamic therapy:Case report. Photodiagnosis Photodyn Ther.2016 Sep;:15:105-8. Photodiagnosis Photodyn Ther.2016 Sep;15:105-8. doi: 10.1016/.jpdpdt.2016.06.001.

19. Asnaashari M, AshrafH, Rahmati A, Amini N. A comparison between effect of photodynamic therapy by LED and calcium hydroxide therapy for root canal disinfection against Enterococcus faecalis: A randomized controlled trial. Photodiagnosis Photodyn Ther.2017 Mar;17:226-32. Photodiagnosis Photodyn Ther.2017 Mar;17:226-232. doi:10.1016/.jpdpdt.2016.12.009. 
20. Moreira MSNA, de FreitasArchilla JR, LascalaCA, Ramalho KM, GutknechtN, Marques MM. Post-treatment apical periodontitis successfully treated with antimicrobial photodynamic therapy via sinus tract and laser phototherapy: report of two cases. Photomed Laser Surg. 20150ct;33(10):524-8. doi:10.1089/ pho.2015.3936.

21. Chen H-M, Chen C-T, Yang H, Lee M-I, Kuo MY-P,Kuo Y-S, et al. Successful treatment of an extensive verrucous carcinoma with topical 5-aminolevulinic acid-mediated photodynamic therapy. J Oral Pathol Med. 2005 Apr;34(4):2536. doi:10.1111/.1.1600-0714.2004.00267.x

22. Aghahosseini F,Arbabi-KalatiF,Fashtami LA, Fateh M, Djavid GE. Treatment of oral lichen planus with photodynamic therapy mediated methylene blue: a case report. Med Oral Patol Oral Cir Bucal. 2006 Mar 1;11(2):E126-9.

23. Sperandio FF, Marotti J, Aranha ACC,Eduardo C de P. Photodynamic therapy for the treatment of recurrent herpes labialis: preliminary results. Gen Dent. 2009 Aug;57(4):415-9.

24. Siddiqui SH, Awan KH, Javed F. Bactericidal efficacy of photodynamic therapy against Enterococcus faecalis in infected root canals: a systematic literature review. Photodiagnosis Photodyn Ther.2013 Dec;10(4):632-43. doi:10.1016/j. pdpdt.2013.07.006.

25. Fransson H, Larsson KM, WolfE. Efficacy of lasers as an adjunct to chemomechanical disinfection of infected root canals: a systematic review. Int Endod J.2013 Apr;46(4):296-307. doi: 10.1111/iej.12003.

26. Genovese WJ, dos Santos MTBR, FaloppaF, de Souza Merli LA. The use of surgical diode laser in oral hemangioma: a case report. Photomed Laser Surg. 2010 Feb;28(1):147-51. doi:10.1089/pho.2008.2419.
27. Saetti R, Silvestrini M,Cutrone C, Narne S. Treatment of congenital subglottic hemangiomas: our experience compared with reports in the literature. Arch Otolaryngol Head Neck Surg. 2008 Aug;134(8):848-51. doi: 10.1001/ archotol.134.8.848

28. Aras MH, Göregen M, Güngörmüş M, Akgül HM. Comparison of diode laser and Er:YAG lasers in the treatment of ankyloglossia. Photomed Laser Surg. 2010 Apr;28(2):173-7. doi:10.1089/pho.2009.2498.

29. Fimple JL, Fontana CR, Foschi F, Ruggiero K, Song X, Pagonis TC, etal. Photodynamic treatment of endodontic polymicrobial infection in vitro. $J$ Endod. 2008 Jun;34(6):728-34. doi:10.1016/j.joen.2008.03.011.

30. Knorst JK, Barriquello GS, Villetti MA, Santos RCV, Kantorski KZ. Antimicrobial effect of methylene blue formulations with oxygen carrier at different $\mathrm{pHs}$ : preliminary study. BrazDent Sci. 2019;22(1):39-45. doi: 10.14295/bds.2018. v22i1.1635.

31. Garcez AS, Fregnani ER, Rodriguez HM, Nunez SC, Sabino CP, Suzuki H, et al. The use of optical fiber in endodontic photodynamic therapy. Is it really relevant? Lasers Med Sci. 2013 Jan;28(1):79-85.

32. Benvindo RG, Braun G, Carvalho AR de, Bertolini GRF.Efeitos da terapia fotodinâmica e de umaúnica aplicação de laser de baixa potência em bactérias in vitro. Fisioter Pesqui. 2008;15(1):53-7.

33. Rosa RA da, Santini MF, Figueiredo JAP de, Visioli F,Pereira JR, Vivan RR, et al. Effectiveness of photodynamic therapy associated with irrigants over two biofilm models. Photodiagnosis Photodyn Ther.2017 Dec;20:169-174. doi: 10.1016/.jpdpdt.2017.10.003.

\section{Amjad Abu Hasna \\ (Corresponding address)}

Av. Eng. Francisco José Longo, 777, Jd São Dimas, 12245-

000, São José dos Campos, SP, Brasil.

e-mail: d.d.s.amjad@gmail.com

Date submitted: 2019 Mar 01

Accept submission: 2019 Jul 05 